\title{
Seeing is believing: symbolic politics and the opportunities of nondemocratic transition in Angola.
}

Following the resignation of President José Eduardo dos Santos after 38 years in power, the August 2017 elections in Angola were peaceful, yet of questionable results and returned the ruling party, MPLA, to power. However, in his first three months in office, the new President, João Lourenço has proceeded to some high-profile reshuffles and symbolic actions that have induced a palpable sense of optimism in the broader population, which seemed bardly warranted before the elections. This article reassesses the outcome of the elections from an Angolan perspective, based on fieldwork carried out in the capital, Luanda and the northern province of Uige shortly after the polls. By examining how certain actions become symbols and what those symbols enable among Angolan citizens, the article offers a discussion of the weight of symbolic politics and the opportunities for change under conditions that fall short of formal standards of democratic process.

In late August 2017 Angola went to the polls for the third time since the end of its nearly 30-year-long civil war in 2002. This time, however, José Eduardo dos Santos, who had ruled the country for 38 years, did not stand again as his party's candidate, having in early 2017 announced his 'retirement from active politics' for 2018. In his stead, the MPLA party - the Popular Liberation Movement of Angola, which has dominated Angolan politics since independence in 1975 - fielded João Lourenço as its head of list and presidential candidate. Dos Santos and his family had since 2011 become the focal point of small, but highly visible youth protests, which demanded an end to his (mis-)rule, clamouring for change and a betterment of the socio-economic conditions of the population. Dos Santos stepping back came as a welcome surprise to most, but Lourenço, who had last served as Minister of Defence, seemed an unlikely candidate for change, given his trajectory within the party and the army, his liberation war credentials, and his demonstrated deference to dos Santos. He was widely seen as a rather lacklustre character, with some Angolan commentators calling him 'dull' and 'not previously known for his intellectual capacities', although he enjoyed, in direct comparison to some of his party comrades, a reputation of relative probity ${ }^{1}$. While he was soon nicknamed 'JLo' by the population, his campaign, running under the motto 'correct what is bad, improve what is good' (corrigir o que está mal, melhorar o que está bem), failed to ignite much 
enthusiasm ahead of the elections. Moreover, dos Santos would remain head of the ruling party for the foreseeable future, which raised doubts about Lourenço's capacity to take autonomous decisions.

Election day itself was orderly and peaceful, despite reports of targeted voter disenfranchisement. The following day, however, the National Electoral Commission, nominally independent but dominated by the MPLA, announced a 61 per cent MPLA victory out of thin air: none of the provincial results had been tallied and parallel counting by the opposition indicated substantial opposition gains in key urban areas. Opposition injunctions to the Supreme Court were, unsurprisingly, dismissed, and despite some feeble protests, Lourenço was duly sworn in. This promised a continuation of the ruinous rule of the MPLA for the coming five years at least - or so it appeared. Yet three months after the elections one could start noting a palpable sense of optimism amongst Angolans, who, together with many Angola-watchers have been surprised by the pace of change.

\section{Neo-authoritarianism: more than big-man rule}

Like a number of African 'post-liberation' regimes, Angola bears the hallmarks of a typical, fairly stable 'neo-authoritarian' regime - the restrictions of press freedom, the rigging of electoral processes, the abuse of the privileges of incumbency, elaborate schemes of crony capitalism rewarding the politically connected, as well as the strict control of the spaces for independent and dissenting expression. Angola vies with Nigeria for the top spot of Africa's oil-producing countries, yet as a Portuguese-speaking country that is still difficult to access, it remains largely unknown to the wider public outside the Lusophone world. Held as a paradigmatic case of 'illiberal peacebuilding' (Soares de Oliveira 2011), the country posted record growth rates from 2002 till 2014, when a crash in world oil prices sent the country's oil-dependent economy into a tailspin. This further aggravated the hardships for a large majority of the urban and rural population, who remained excluded from the previous economic growth and the muchtouted 'benefits of peace' (Schubert 2015). A number of small but highly visible protests since 2011 were violently repressed; however, after the oil price crash the government intensified its repression. Rather than admitting the severity of the economic crisis, which had been aggravated by profligate spending, mismanagement and elite embezzlement of public funds, the government unleashed the most violent persecution of internal 
enemies' since the end of the war. Back then the dominant sentiment was dos Santos was willing to cling to power by any means possible.

Much of the commentary on Angola (and often, too, in similar socio-political contexts) tends to explain the 'authoritarian dispensation' in place through a combination of patronage, coercion, and an apathetic citizenry, too traumatized by the combined effects of the civil war and a turn to predatory capitalism to develop an independent political consciousness. There is a dominant Western discourse on autocratic rulers which is based on the idea that one man wields power (Krohn-Hansen 2008), resulting in an obsession with personal rule (and the admittedly oftentimes fascinating excesses of power), which ultimately risks reproducing the idea of unchanging Africa, mired in corruption and big-man politics. The long-standing autocrats of this world are (or were, in the case of Angola's dos Santos and Zimbabwe's Robert Mugabe) clearly shrewd political operators, but, 'even in the most repressive regimes, political power is far more dispersed and transactional than is most often assumed' (Krohn-Hansen 2008, 8). Therefore, 'the analysis of authoritarian rule ought to be solidly rooted in examinations of everyday life' and should 'view authoritarian states as sets of cultural processes' (Krohn-Hansen 2008: 5; see also Jourde 2009: 203-04). And yet, despite these justified anthropological criticisms of analyses of 'big-man rule', my recent fieldwork in Angola suggests that the change of the figure at the top has already had significant symbolic impact on the political subjectivities of Angolans, which in turn opens up new spaces for debate (and potentially action). So how to make sense of the apparent importance of replacing one person while leaving the structures of power seemingly untouched from an anthropological perspective? Ethnography can reveal and render intelligible political formations 'below the threshold of visibility for normative conceptions of political action' (von Schnitzler 2016: 9), and give us a different perspective on the cultural processes that reproduce dominance in the everyday. Returning to the 'logic of practice' of highly personalised power (Wedeen 1999: 25), might help us understand how a visible shift in the 'aesthetics of power' (Mbembe 2001) could very quickly have noticeable effects on political culture in everyday practice.

\section{Seeing is believing: the weight of symbols}

How can we then account for the importance given by Angolans to Lourenço's election? I suggest this has to do with the weight of symbols in a political system shaped by strong personalisation and deference to hierarchy. Let us briefly cut back to 2011: In the 
everyday chaos of Luanda's traffic jams, the presence of powerful SUVs was a signifier of real-life power relations, with the presidential motorcade as the most powerful of these signifiers. Whenever President dos Santos moved through the city, traffic lanes were blocked, sometimes hours in advance, by heavily armed soldiers and Presidential Guard Unit troops positioned every hundred metres. And what a spectacle it was when he finally rushed through: preceded by police motorcycle outriders, 5 gleaming black GClass Mercedes with tinted windows sped past the immobilised onlookers, followed by an ambulance, two pick-ups carrying the heavily armed Presidential Guard, a black Toyota Prado, one light troop carrier, and further police motorcycles. When traffic was light, the motorcade rushed by, like a fleeting apparition, but most of the times the rest of the road users got stuck in the roadblocks for several hours during which nothing moved. 'When Zé Dollar [dos Santos] passes, the country stands still — he’s really Zé Dollar', commented a driver of a collective taxi. This truly epitomized presidential grandiosity, the spectacle of symbolic violence and obscenity that are an integral part of a 'generalised aesthetics and stylistics of power' in Sub-Saharan Africa that bind the ruler and the ruled in mutual 'zombification' (Mbembe 2001: 104, 115).

Fast forward to 2017, 3 months after Lourenço's election: the actual focus of my research was on experiences of the Northern Front during Angola's civil war, but both in formal interview settings and spontaneous chats the new president came up time and again, and in my conversations and observations the sense of optimism was palpable. The contrast was especially striking when compared to my previous research in and on Angola since 2007, in which the last years of dos Santos' rule left many people jaded and deeply pessimistic for the country's future. I spoke to street-side traders and moneychangers, to church elders, state functionaries, entrepreneurs and academics, as well as to politicians and former commanders of the major opposition party (and former rebel movement) UNITA. The latter were somewhat guarded, though willing to give Lourenço the benefit of doubt. To my surprise, however, most others, regardless of their usually often critical stance toward the rule of the MPLA in recent years, were positively swooning over 'o kota JLo' (an endearing Kimbundu/Luanda slang term for 'elder'). They remarked especially on his 'humility' and simplicity, and contrasting this with the experience of dos Santos. Indeed, Lourenço only travels with one motorcycle outrider, the armed sentinels and street closures have disappeared, and he even ordered his convoy to stop at the red light!' He also, I was told in a mixture of wonder and glee, queued at the KFC like an ordinary citizen, and made a private visit to a friend who was 
in hospital, driving his own car and entering the premises of the hospital unguarded, in the only company of his wife.

In the week leading up to Independence Day (11 Nov) Lourenço visited the restive province of Cabinda — 'and he slept in the province, can you imagine? The Old Man [dos Santos] never did that in 38 years - if he went to the provinces, he would stay for 3 to 4 hours maximum, and then quickly escape back to his palace!' The official celebrations of Dipanda (the Angolan term for independence) were then staged in the municipality of Matala, in the southern province of Huíla. When Lourenço's plane touched down in the provincial capital, Lubango, a welcome committee of MPLA, OMA (Organização da Mulher Angolana, the MPLA's women's wing) and OPA (Organização Pioneiros Agostinho Neto, the youth/pioneer movement of the party) were waiting for him, waving party flags. Lourenço, however, refused to leave the plane until they all had left, saying he was here as president for the entire country, not of the party.

At first, this all seemed like purely symbolic politics. But the importance of such symbols should not be underestimated. 'O Angolano quer ver para crer' (Angolans want to see to believe), I was repeatedly told. As one friend, a lawyer in his late thirties told me, 'We need to see some improvements to our lives, otherwise why bother with elections? And I think João Lourenço has made a clear analysis of the situation, and he knows that he has to listen to the people in the current situation, or else the people will go out and protest. That's why he's acting closer to the people, more humbly — if he has the backing of the population, then the MPLA will not be able to oppose his plans. Conversely, if he listens to the MPLA and not the people, it will be very bad. The people will turn against the MPLA saying "let the man work!" ,

\section{Reassessing the elections}

Accordingly, while the 2017 election results appeared more or less fabricated out of thin air (Pearce et al. 2018, 7-8), a disillusioned outside perspective that only picks up on the shortcomings of the elections has to undergo a corrective, when viewed from Angola. Despite a less-than-perfect electoral process, replacing dos Santos evidently counted for a lot. Angolans are overall lucid about the flaws of the elections, and harbour little illusions that the democratic system would now all of a sudden be fixed, but nonetheless the change the elections marked is real and is having an impact on individuals and the possibilities of collective action. My interlocutors made the following points to clarify their view on this: JLo is now much more popular than before the elections (cue the 
KFC and red light episodes), and that the chant of Lourenço amigo, o povo está contigo (Lourenço, friend, the people stand with you), an old MPLA slogan that had sounded increasingly hollow under dos Santos, is no longer completely off the mark. Dos Santos, by contrast is now massively unpopular, even 'within the party there are guys who can no longer stand him, who can no longer look him in the eye', as several long-standing MPLA members (some of whom more critical than others) told me.

As two of my Angolan colleagues vividly discussed over a lunch in a popular buffet place, Lourenço apparently wanted to go into the elections 'a peito aberto' (openly), to gauge how popular he and the party really were. 'And the camaradas said, "OK, we'll let you see what happens", but they still put in place the whole machinery [of fraud]. On the evening of the elections, JLo went to the party HQs to await results there. But when the results started coming in, they realised they had lost control, and that with the fraud of previous years alone [voter disenfranchisement, ballot-stuffing and voter-buying in the provinces, see Roque (2013); Schubert (2010)] they would still lose. That's when they decided to announce victory regardless of the numbers - and that's why JLo left, angry, after half an hour only [meaning, according to my colleagues, that he did want to win without having to resort to fraud]. Then Camarada Jú Martins [a shadowy party strategist] announced the resounding victory of the Eme with $65 \%$ — though he could not state it very convincingly'. Especially the last point about Martins speaks to Angolans' long experience of decoding and interpreting the public visibility and disappearance of party members.

Similarly, an outside perspective that chastises opposition parties as weak or even spineless for not mounting a more robust challenge to the results does not entirely hold up to scrutiny when viewed from Angola. As the discussion over lunch continued, UNITA, Angola's main opposition party and former 'rebel group' during the civil war, may know the 'real' numbers of the election results, but they are not making them public (this is a statement I heard repeatedly). However, the party's leader, Isaías Samakuva showed great restraint in accepting the results — in fact, according to many, Samakuva is the man of the hour who 'saved' peace in Angola by accepting the results. According to my colleagues, 'Samakuva said at a UNITA rally in 2015 that he had received a [symbolic] whistle (o apito da alvorada) from Savimbi, [UNITA's larger-than-life founder, killed in combat in 2002], and that "if they continue to chatear (harass) us, I will blow that whistle!" All the young hotheads cried out "blow it now, blow it now!" after which Samakuva had to brake and calm down everything. Now again, some youths were eager 
to prove their willingness to die and contest the results in the street, but Samakuva restrained them and everyone in the party. If they had had a maluco (crazy man) like Numa [a former high-level UNITA military commander and ex-deputy] as head of the party, nem pensar (perish the thought) what could have happened. Because the army would not allow that — it would have been a bloodbath, many people killed'. The last idea, that Samakuva prevented an escalation of violence by recommending that youth activists not take the streets (cf. Pearce et al. 2018, 11), was echoed by several interlocutors, who still actively remember the time of the war. The rumours surrounding the election, often circulated in closed WhatsApp groups among party members, indicate that the conspiratorial mode of understanding politics still lives on among Angolan citizens. The — real or imagined — fear of a bloodbath especially speaks to the affective charge of embodied experiences (cf. Laszczkowski and Reeves 2015) of living with a state power that has historically often been experienced as arbitrary, and with the power to violently disrupt people's lives. More than only the war, in fact, the memory of the repression unleashed by the MPLA against its own following the 27 May 1977 still casts a long shadow, and is often cited both by regime supporters and detractors as the main reason why it is dangerous to openly contest the party in power (Pawson 2014, Schubert 2017).

\section{The opportunities of nondemocratic transition}

Why then the optimism about Lourenço, despite overall agreement that the elections were far from free and fair? During the last decade of the rule of ex-president dos Santos, the personalisation and strong hierarchisation of social relations, as well as the imagery that goes with it, fostered, according to many, a 'culture of sim chefe' (yes boss) in the administration, where no one was willing to take any independent decision for fear of the chefe's possible reprisals, such as losing their position in one of the frequent administrative reshuffles. However, this pervasive imagery of hierarchy goes beyond the public administration. This is how power works in Angola, because people perceive it as such across the social strata.

During the dos Santos years, whichever decision was taken, whichever action carried out, it was done with reference to ominous orientaçôes superiores (higher directives) that may well have come from the President himself. In Mozambique, Euclides Gonçalves has shown that similar orientações superiores circulate as provisional instructions providing "parameters for action without being precise" but in the form of actual drafts 
or public pronouncements by senior state and party officials (Gonçalves 2013, 610-1). In Angola, by contrast, it very often remained unclear whether instructions were really issued, or whether individuals were only acting out what they imagined to be the will of the chefe in pre-emptive obedience (what is in German called vorauseilender Gehorsam, or obedience hurrying ahead). Merely invoking these higher directives then justified all courses of action, ranging from police brutality to administrative and judicial arbitrariness. The vagueness of the formulation certainly served its purpose of obscuring the lines of command and reinforcing the nebulousness of power - as well as, ultimately, absolving the figure of the President from any personal responsibility for the misdeeds of his underlings.

However, much as the culture of pre-emptive obedience served to close down spaces under dos Santos, the practice of following orientações superiores now appears to be opening spaces. It was instructive to see how Lourenço's speeches were meticulously dissected by my friends and interviewees, and how every word was weighted for its possible political relevance. While in the electoral campaigns the 'bad' things that needed correcting were never clearly identified, Lourenço called out various evils such as corruption in his inaugural speech. He did not name any names, but Angolans who have learnt through years of practice to read between the lines and expressing grievances through rumours and gossip (J. Gonçalves 2017, 241, e.g.) said it was evident who he meant, and said their days were counted - the nebulous, yet often specifically identified eles (they), the leading figures from dos Santos' entourage and his family.

Lourenço also denounced the lack of unbiased reporting in the state media, which he said should serve the people, not the party. Jornal de Angola, the only daily newspaper, as well as the public TV broadcasters, all had in the past years mainly been known for their increasingly absurdist denial of reality and insistence that everything was fine in the country, leaving Angolans only dark humour as possible response (Kligman 1998). However, almost overnight some news items appeared that, if not outright critical reporting, at least admitted that some things were not quite as perfect as they had until now been made out to be. Several weeks later, Lourenço appointed a new board of directors for the Jornal, thereby formalising the new direction he'd already outlined in his speech. ${ }^{2}$

2 Since then, opposition members have been given space to write opinion columns; journalists are now also admitted to cover debates at the National Assembly. 
This willingness to seize the opportunities hinted at in official statements, and interpret them in practice as an exhortation to reform was echoed by a friend working for an oil multinational: 'even if he's not a real reformer, there are so many people like us everywhere, willing to seize whichever small space they are granted by new laws, regulations, or simply a new spirit that the door cannot be closed again'. What this shows, I think, is how Lourenço's — so far largely symbolic — decisions had immediate impact on the decisions made by everyday people.

This speaks to the weight of political signals given at the top beyond the case of Angola. Societies change before formal changes are enacted. To give an example from a different context, the hardening stance of the UK Home Office and its increasing propensity to forcibly deporting individuals and even separating families settled in the UK could be noted before any new laws or decrees were signed. Rather, this change in practice likely happened because the Tory party leadership clearly signalled it was in the national interest to do so. ${ }^{3}$ Very similar arguments have been made about how President Trump's statements have shifted the boundaries of what was publicly acceptable in the US since his election, with some branches of the government seizing that space more enthusiastically than others. The normalisation of racist statements in the public in both cases (Shore 2016, Stoler 2017, e.g.) are a further indication of the importance of signals given 'at the top' of a hierarchically organized political system. For every such example, there are obviously also counter-examples, such as Fuglerud's work on asylum claims in Sweden, which shows how public functionaries embody a sense of duty that they hold independent of shifts in political leadership, going as far as 'correcting' the excessive hardening or liberalisation of the immigration regime by successive ministers in their daily work (2004). Recent news of German commercial airline pilots refusing to take off when forcibly repatriated asylum seekers are on board are another case in point, ${ }^{4}$ as are the functionaries in the US Environmental Protection Agency who have vowed to resist President Trump's repeal of certain regulations. ${ }^{5}$

In the case of Angola, there had certainly also been instances of more autonomous decision-making in the public administration under dos Santos, yet these were often individual decisions, and fraught with risk, as they went against the imputed

3 Though arguably Theresa May’s previous leadership of the Home Office certainly made sure that this new spirit was duly implemented early on.

4 https:/www.independent.co.uk/news/world/europe/german-pilots-refuse-deport-asylum-seekerslufthansa-angela-merkel-migrants-a8092276.html (accessed 6 Dec 2017).

5 http://uk.businessinsider.com/how-to-resist-trumps-agenda-by-ex-epa-staffers-2017-7?r=US\&IR=T (accessed 6 Feb 2018). 
will of the 'higher orders', and were often curtailed by detailed presidential decrees. Now, the sense of relief appeared palpable. In a context where authority is excessively hierarchical and the public administration so evidently partisan (Schubert 2010: 659), acting more independently apparently required a strong signal from the top that it was now $\mathrm{OK}$ to do so.

I would not go as far as to postulate a direct link between instances of preemptive obedience and the authoritarian tendencies inherent to the respective polity, but the willingness expressed by many of my informants to push for change and widen the spaces made available to them confounds the hitherto predominant idea of a leaden 'culture of fear' cowing the population into submission. True, until before the last elections, the overall impression was still that embodied knowledge about the ubiquity of surveillance by the state security services produced 'political subjects and subject dispositions useful to the regime' (Verdery 1996: 24). Now, however, the rapid, visible waning of dos Santos' influence in the realm of formal and party politics has opened up possibilities for people, from party loyalists to ordinary citizens, to openly and publicly criticize dos Santos for his failings over the past ten years: 'Esse camarada assegurou a paz, muito bem. Mas a factura ficou muito pesada...' (This Comrade secured peace, alright. But the bill was very hefty), is how my barber, for example, concluded his 30-minute long tirade. So much of what happens in Angola is not just about official directives from the top, but based on informal signals ('higher directives'). Angolans, who have learnt during years of authoritarian rule to decode and interpret these signals, now appear to feel that all the signals align to indicate the possibility of opening and reform. And thus, Lourenço's campaign motto has been picked up and reappropriated to formulate citizens' hopes for change, appearing in unexpected places such as a wooden board at a carwash by a river crossing outside of the provincial capital of Uíge: 'correct what is bad, improve what is good'.

This suggests that there is potential for political change, even in a system experienced as totalising as the one in Angola. I would argue that change in such a context of neo-authoritarianism will be most effective when formulated from within the parameters of the system (Schubert 2017): in deference to hierarchy, and through repertoires that are culturally resonant (i.e. inspiring a population hungry for change) but that are also legible to power, allowing for the responsiveness of $o$ poder (power), without it having to appear to 'giving in' to more confrontational challenges to the regime, such as those mounted by the 'youth protesters' in the past five years. 


\section{Conclusion}

It remains to be seen whether the highly symbolic actions of Lourenço will translate into the 'real change' Angolans are hoping for. In the first three months, he has made 250 new appointments, as well as a number of very high-profile dismissals, designed to gain control over the administration and parastatals by purging them of dos Santos loyalists. This included, most notably, removing Isabel dos Santos, daughter of José Eduardo dos Santos and Africa's wealthiest woman, from her position as head of state oil company Sonangol, cancelling a contract between a production company of two other of president dos Santos' children and two of the three TV broadcasting companies, and finally also dismissing José Filomeno 'Zénú' dos Santos as chairman of the Angolan Sovereign Wealth Fund in January 2018. Overturning especially Isabel's appointment, which had been deeply unpopular even within the party, further bolsters Lourenço's popularity.

Many are rightly asking whether this is not just a game of musical chairs (dança das cadeiras) in which a new network of beneficiaries connected to Lourenço will take the place of the previous one. This might be too early to tell: his wife, the economist Ana Dias Lourenço, had previously been the Executive Director for Africa at the World Bank, and has a good reputation in Angola, and their six children have until now kept a low profile, though the independent Angolan news site Club-K suggested that Lourenço's early nominations were based on shared family or business links. ${ }^{6}$ Moreover, while the dos Santos family were certainly the most visible beneficiaries of the system, they were by far the only ones. It is far from certain that Lourenço will attack the economic oligopolies of the army's 'business generals' with the same zeal as he appears to tackle the interests of the dos Santos (cf. Pearce et al. 2018, 14-15). The judiciary for now also remains deeply partisan, and the long-promised 'diversification of the economy' will also take more than just the removal of Isabel dos Santos to happen. As some more skeptical Angolan commentators have noted, he has not done anything laudable yet. As opposition deputy Mihela Webba said, 'the people cannot live on dismissals and appointments alone. When the people see the economic reality that we cannot live off our salaries, with the existing sanitation, with the lack of drugs and hospitals that are not working, the disillusionment will start'. ${ }^{7}$ And there seems, for now, little hope that

6 Club-K, 'Novas nomeações baseadas no compadrio' http://mail.clubk.net/index.php?option $=$ com content\&view $=$ article $\& \mathrm{id}=29617$ :nomeacoes-baseadas-nocompadrio\&catid $=8$ :bastidores\&lang $=$ pt\&Itemid $=1071$, accessed 8 Feb 2018.

7 'O povo não vive só com exonerações e nomeações ... Quando vier a realidade económica de que não se pode viver com os salários que existem, com o saneamento que existe, com a falta de medicamentos, com hospitais que não funcionam, a desilusão vai começar' VOA Português, 
parliamentary politics will prove a more effective counterweight to the constitutional dominance of the executive in this time of crisis, with opposition deputies until now primarily reaffirming their rights to privileges of office such as expensive, state-bought luxury limousines.

Still, the symbolism of the changes at the top is evident, and Lourenço seems willing to use the near-absolute powers the 2010 constitution gives the president to emancipate himself from the shadow of dos Santos. While central elements of Angolan political culture — the deference to hierarchy, the importance of family links, the weight of history, and the MPLA's stated belief in its right to direct the country's destiny (Schubert 2017) - are likely to be more durable than just the next electoral cycle, 'JLo' for many now incarnates the possibility of change. The marked contrast of his first public actions to dos Santos' style of rule has opened up symbolic opportunities that Angolans appear to be willing to seize. After 38 years of ditadura dos kotas (dictatorship of the elders) this has raised justified hopes that o poder might just become a little more responsive to their everyday concerns.

\section{References}

Fuglerud, Oivind. 2004. Constructing exclusion. The micro-sociology of an immigration department. Social Anthropology 12 (1), 25-40.

Gonçalves, Euclides. 2013. Orientações superiores: time and bureaucratic authority in Mozambique. African Affairs, 112(449), 602-22.

Gonçalves, Jonuel. 2017. On Angola as a battlefield. Citizenship Studies, 21(2), 240-54.

Jourde, Cédric. 2009. The ethnographic sensibility: overlooked authoritarian dynamics and Islamic ambivalences in West Africa. In: E. Schatz, ed. Political Ethnography: What Immersion Contributes to the Study of Power. Chicago, Ill. ; London: The University of Chicago Press, pp. 201-16.

Kligman, Gail. 1998. The Politics of Duplicity: Controlling Reproduction in Ceausescu's Romania. Berkeley, CA; London: University of California Press.

Krohn-Hansen, Christian. 2008. Political authoritarianism in the Dominican Republic. New York, NY: Palgrave Macmillan.

Laszczkowski, Mateusz and Madeleine Reeves. 2015. Introduction: affective statesentanglements, suspensions, suspicions. Social Analysis, 59(4), 1-14.

Mbembe, Achille. 2001. On the postcolony. Berkeley, Los Angeles, London: University of California Press.

Pawson, Lara. 2014. In the Name of the People: Angola's Forgotten Massacre. London; New York; Melbourne: I.B. Tauris.

Pearce, Justin, Didier Péclard, and Ricardo Soares de Oliveira. 2018. Angola's Elections and the Politics of Presidential Succession. African Affairs.

12.01.2018, “Angola Fala Só - Mihaela Webba: "Não só de exonerações vive o povo"' https://www.voaportugues.com/a/angola-fala-so-miahela-webba-nao-so-de-exoneracoes-vice-opovo/4204759.html (accessed 17 Jan 2018) 
Roque, Paula C. 2013. Angola's Second Post-War Elections. The Alchemy of Change. Johannesburg: ISS, No. May 2013.

von Schnitzler, Antina. 2016. Democracy's infrastructure: techno-politics and protest after Apartheid. Princeton, NJ: Princeton University Press.

Schubert, Jon. 2010. 'Democratisation' and the consolidation of political authority in post-war Angola. Journal of Southern African Studies, 36(3), 657-72.

Schubert, Jon. 2015. 2002, Year Zero: History as Anti-Politics in the New Angola. Journal of Southern African Studies, 41(4), 835-52.

Schubert, Jon. 2017. Working the system: a political ethnography of the new Angola. Ithaca, NY; London: Cornell University Press.

Shore, Cris. 2016. Brexit Referendum: first reactions from anthropology. Social Anthropology, 24(4), 478-502.

Soares de Oliveira, Ricardo. 2011. Illiberal peacebuilding in Angola. The Journal of Modern African Studies, 49(2), 287-314.

Stoler, Ann L. 2017. "Interior frontiers" as political concept, diagnostic, and dispositif. Cultural Anthropology website. Available from: https://culanth.org/fieldsights/1045-interiorfrontiers-as-political-concept-diagnostic-and-dispositif [Accessed 3 Dec 2017].

Verdery, Katherine. 1996. What was socialism, and what comes next? Princeton: Princeton University Press.

Wedeen, Lisa. 1999. Ambiguities of domination: politics, rhetoric, and symbols in contemporary Syria. Chicago; London: University of Chicago Press.

Jon Schubert is currently a senior research fellow at the University of Geneva. His present research, funded by the Swiss Network of International Studies (SNIS), focuses on legitimacy and institution building during the Angolan civil war. He has previously worked on political authority in Angola and on natural resource extraction and public functionaries in Mozambique. His email is jon.schubert@unige.ch 